\title{
Assessment of Well drinking Water Quality in Samrab, Dardog and Hattab Communities, Khartoum North, Sudan
}

\author{
Hago M. Abdel-Magid ${ }^{1}$, Abdelmonem M. Abdellah², Sara M. Abbkar ${ }^{3}$ \\ and Fathia A. Adam ${ }^{4}$ \\ ${ }^{l}$ Dept. of Soil and Environment Sciences, Faculty of Agriculture, University of Khartoum, Sudan, \\ ${ }^{2}$ Allahawi for Research Consultation (ARC), Safa Trading Center, Khartoum North, Sudan, \\ ${ }^{3}$ Faculty of Agric. Production and Processing Technology, Intern. Univ. of Africa, Sudan, \\ ${ }^{4}$ Dept. of Chemistry, Faculty of Science and Arts, King Khalid University, Belgrn, Kingdom of Saudi Arabian, \\ respectively.
}

\begin{abstract}
The quality of drinking water in some of the northern suburb communities of Khartoum North, Sudan was investigated with respect to electrical conductivity $(E C)$, total dissolved salts $(T D S), p H$, major ions $\left(\mathrm{Ca}^{+2}\right.$, $\mathrm{Mg}^{+2}, \mathrm{Na}^{+}, \mathrm{K}^{+}, \mathrm{SO}_{4}^{-2}, \mathrm{NO}_{3}^{-}, \mathrm{HCO}_{3}^{-}, \mathrm{Cl}^{-}$) and total iron, beside coliform bacteria (E.coli and streptococci) as an indicators of fecal contamination. The results obtained revealed that $20 \%$ of the samples were above the maximum limit of both $1.6 \mathrm{dSm}^{-1}$ and $1000 \mathrm{mgl}^{-1}$ set by SSMO and WHO for EC and TDS, respectively. About $25 \%$ of the samples exceeded the maximum limit of $200 \mathrm{mg} / \mathrm{l} \mathrm{set} \mathrm{by} \mathrm{SSMO}$ and $\mathrm{WHO}$ for $\mathrm{Na}^{+}$. Most of the major ions and total iron were found within the recommended limits of the local, regional and international standards of drinking water. Microbiological analyses indicated that 55\% of the samples were contaminated with coliform bacteria. It may be recommended that continuous assessment of drinking water quality, on routine basis, is imperative and a better management and monitoring are warranted to reduce the deterioration of aquifer water quality in the region.
\end{abstract}

Keywords: Water quality, contamination, major ions, coliform, standards.

\section{Introduction}

During the last decade, it has been observed that groundwater is vulnerable to pollution due to the increasing urbanization and human activities. Consequently a number of cases related to water borne diseases were detected which may be linked to deterioration of water quality. Therefore, basic monitoring on water quality is deemed necessary to cope with the rising demand and hence the expected, pollution risk level of groundwater (Abdel Magid, 2016). A good number of water analysis experiments were regularly conducted by different groups of chemists and biologists in this regard (Abdel Magid et al.,1984; Abdel Magid, 1997; Redhaiman and Abdel Magid, 2002, Shomo, 2007; Abdellah et al., 2013). Based on taste, Abdellah et al. (2013) suggested the following classification for groundwater on the basis of TDS level: 1) < $200 \mathrm{mg}$ TDS/l as palatable water ; 2) 200 - $500 \mathrm{mg}$ TDS/l as potable water ; 3) 500 - $750 \mathrm{mg} \mathrm{TDS} / \mathrm{l}$ as none palatable water ; 4) $750-1000 \mathrm{mg}$ TDS/l as salty taste water ; 5) $1000-1500 \mathrm{mg}$ TDS/l as saline water ; and 6) > $1500 \mathrm{mg} / \mathrm{l}$ TDS as brine water . However, water used for drinking purposes should be free of suspended impurities, dissolved harmful salt and disease - causing microorganisms. The suitability of groundwater resources is determined by both the quality of the water and by the available yield. The chemical quality of groundwater depends primarily on the level of TDS (Abdellah et al., 2014). Equivocal and undocumented concern indicated that potential health hazards may arise from drinking saline and bacteriologically contaminated water in the area of study since the drinking water is still distributed by vendors on donkey mounted water distribution carts (Plate 1 and 2). However, absence of current or previous aquifers study data for wells drilling, legislations and sanitary laws may accentuate the problem. The main objectives of this study are to evaluate the physico - chemical and the microbiological characteristics of well water samples collected from diverse drinking water sources in the study area and to compare the results obtained with the local (national), regional and international standards and guidelines.

\section{Description of study area:}

\section{Materials And Methods}

The area under study is located at the northern eastern part of Greater Khartoum State, Sudan. Wells under investigation were drilled in Samrab, Dardog, and Hattab suburban communities. Khartoum city the capital of Sudan is located in the central part of the country which is located between latitudes $15^{\circ} 26^{\prime}$ and $15^{\circ} 45^{\prime} \mathrm{N}$ and longitudes $32^{\circ} 25^{\prime}$ and $32^{\circ} 40^{\prime} \mathrm{E}$, at an altitude of $405.6 \mathrm{~m}$ above sea level (Shakesby, 1991). According to Perry (1991), the main climatic conditions of Greater Khartoum are conditioned by its location on 
the southern fringes of the Sahara, the city experiences four climatic seasons, the winter season extends from mid-November to March, with a minimum temperature ranging between $8^{\circ} \mathrm{C}$ and $10^{\circ} \mathrm{C}$ which falls to $5^{\circ} \mathrm{C}$ during night, and maximum temperatures varying from $23^{\circ} \mathrm{C}$ to $25^{\circ} \mathrm{C}$, and a relative humidity which may sometime be as low as 20 per cent, the hot, dry summer season is well in place by the end of March, the maximum temperatures may exceed $45^{\circ} \mathrm{C}$ by the end of May, the rainy season covers the period from July to September, with August being the rainiest month. Generally, annual rainfall ranges between 110 and $200 \mathrm{~mm}$. A short, hot (about $40^{\circ} \mathrm{C}$ ) transitional season occurs between mid-September and the beginning of winter.

\section{Collection of water samples:}

For the physico - chemical tests twenty drinking water samples were collected in clean plastic bottles after rinsing with the sampled tap (public stands water known locally as Sabeel drinking water) or well water at the collection site. For the bacteriological tests the water samples were collected in sterile glass bottles and immediately rushed to the laboratory in iced containers.

\section{Laboratory work:}

Laboratory analyses were mainly carried out at the Dept of Soil \& Environment Sciences, Faculty agriculture, University of Khartoum.

\section{Chemical Examination:}

The $\mathrm{pH}$ value was measured by $\mathrm{pH}$-meter (Jenway. Model: 3510 . England 2009). EC (dS/m at $25^{\circ} \mathrm{C}$ ) was measured by EC-meter (Model: M35. Serial NO: 3405). $\mathrm{Na}^{+}$and $\mathrm{K}^{+}$were determined by flame photometer (Model: PFP7, Jenway-England) according to the APHA $(1985,1998) . \mathrm{Ca}^{+2}$ and $\mathrm{Mg}^{+2}$ were determined by titration with Ethylene Di amine Tetra Acetic acid (EDTA) disodium salt $(0.01 \mathrm{~N})$. Sulfate, nitrate, bicarbonate and chloride were determined according to Richards (1954). Total dissolved salts were determined by multiplying the EC value obtained by (640) according to Rhoades (1982).

\section{Microbiological analyses:}

The media and chemicals used in this study were purchased from Elrebooa CO. Ltd., Assouk-el-Arabi, Khartoum, Sudan. These media and chemicals were used to detect and enumerate different types of microorganisms according to Harrigan (1998) Before sterilization, glassware, to be used in the analysis, was washed thoroughly with deionized water and left to dry and then sterilized in a hot oven at $160^{\circ} \mathrm{C}$ for at least $3 \mathrm{~h}$ (Harrigan and McCane, 1976). Instruments such as loops, needles, forceps, spoons and knives were sterilized by flaming directly after dipping in spirit.. The total viable count of bacteria was carried out by using the pour plate count method. For the determination of coliform bacteria in water samples, the multiple tube technique was used according to Harrigan (1998). This method is known as the dilution method or Most Probable Number (MPN) technique. The number of positive tubes was calculated from the MPN tables and the results were recorded.

\section{Statistical analysis:}

Statistical analysis of the data obtained were performed using calculator to estimate the mean and standard deviation. The means obtained for the various parameters were evaluated according to the current national (SSMO, 2002), regional (SASO, 1984) and international (USEPA, 1976 and WHO, 1993) drinking water standards and guidelines.

\section{Groundwater samples of Samrab Community:}

\section{Results And Discussion}

The results obtained for the Samrab community well water samples analysis (Table 1) revealed differences in the magnitudes of the various levels of the parameters studied: EC ranged from 0.28 to $0.64 \mathrm{dSm}^{-1}$ (TDS range $=179.2$ to $409.6 \mathrm{mgl}^{-1}$ ) with an average value of $0.45 \mathrm{dSm}^{-1}$ (TDS $=313.8 \mathrm{mgl}^{-1}$. Comparison with the recommended standards and guidelines for drinking water salinity revealed that all of the samples studied are falling within the recommended limits of the national (local), regional and international standards . Likewise,, none of the following parameters, as shown in table 1, is above the guideline limits set by the respective standards : $\mathrm{pH}$ values ranged from 6.5 to 7.1 with an average value of $6.8 . \mathrm{Ca}^{+2}$ concentrations ranged from 1.4 to $3.5 \mathrm{mgl}^{-1}$ with a mean value of $1.9 \mathrm{mgl}^{-1}, . \mathrm{Mg}^{+2}$ concentrations ranged from 1.1 to $2.5 \mathrm{mgl}^{-1}$ with a mean value of $1.6 \mathrm{mgl}^{-1} \cdot \mathrm{Na}^{+}$concentrations ranged from 30 to $141 \mathrm{mgl}^{-1}$ with a mean value of $77.3 \mathrm{mgl}^{-1} \cdot \mathrm{K}^{+}$ concentrations ranged from 2.05 to $4.22 \mathrm{mgl}^{-1}$ with a mean value of $3.34 \mathrm{mgl}^{-1}$. Each of SSMO, SASO, USEPA and WHO standards has not set any guideline value or limit for $\mathrm{K}^{+} . \mathrm{Cl}^{-}$concentrations ranged from 0.3 to $1.8 \mathrm{mgl}^{-1}$ with a mean value of $0.8 \mathrm{mgtandardsl} \mathrm{s}{ }^{-1}$. Tnd internationahe $\mathrm{SO}_{4}^{-2}$ concentrations ranged from 0.0 to $16.5 \mathrm{mgl}^{-1}$ with a mean value of $5.7 \mathrm{mgl}^{-1}$. The $\mathrm{NO}_{3}{ }^{-}$concentrations ranged from 0.3 to $0.9 \mathrm{mgl}^{-1}$ with a mean value of $0.6 \mathrm{mgl}^{-1}$. $\mathrm{HCO}_{3}^{-}$concentrations ranged from 2.6 to $4.6 \mathrm{mgl}^{-1}$ with a mean value of $4.0 \mathrm{mgl}^{-1}$. Each of SSMO, SASO, USEPA and WHO standards has not set any guideline value or limit for $\mathrm{HCO}_{3}{ }^{-}$. 


\section{Well water samples of Dardog Community:}

The results obtained for the Dardog community well water samples analysis (Table 2) are more or less similar in magnitude to those obtained for Samrab community(Table 1) i.e. comparison with the standards and guidelines of drinking water revealed that all of the samples studied are falling within the limits recommended by the national, regional and international standards.

\section{Groundwater samples of Hattab Community:}

The results of the analysis of the water samples from Hattab community with respect to $\mathrm{pH}, \mathrm{Ca}^{+2}$, $\mathrm{Mg}^{+2}, \mathrm{~K}^{+}, \mathrm{Cl}^{-}, \mathrm{SO}_{4}^{-2}, \mathrm{NO}_{3}{ }^{-}$and $\mathrm{HCO}_{3}^{-}$are within the limits recommended by the respective standards (Table 3). However, the EC ranged from 0.88 to $18.0 \mathrm{dSm}^{-1}$ (TDS range $=563$ to $11520 \mathrm{mgl}^{-1}$ ) with a mean value of 5.2 $\mathrm{dSm}^{-1}$ ( TDS $=3296 \mathrm{mgl}^{-1}$ ) by the respective standards. Comparison with the standards and guidelines for salinity of drinking water revealed that $66.7 \%$ of the samples studied are falling above the standard limit of $1.6 \mathrm{dSm}^{-1}$ (TDS $=1000 \mathrm{mgl}^{-1}$ ) set by SSMO, $50 \%$ of the samples are falling above the standard limit of $2.3 \mathrm{dSm}^{-1}$ (TDS $=1500 \mathrm{mgl}^{-1}$ ) set by SASO while $100 \%$ of the samples are falling above the standard limit of $500 \mathrm{mg} \mathrm{l}^{-1}$ set by USEPA guidelines and standards.

High salinity drinking water with TDS levels violating the maximum recommended levels (as that found in some wells of Hattab Community) is considered unsuitable for drinking but could be used for irrigation of crops with good salt tolerance (Al-Redhaiman and Abdel-Magid, 2002). Previous studies indicated that in some of the villages located to the extreme northwestern boundary of the study area the TDS levels were found to range between 1088 and $1952 \mathrm{mg} / \mathrm{l}$ (Abdel-Magid etal., 1984). Abdellah et al. (2013,2014) reported a TDS level ranging between 97 and $2600 \mathrm{mg} / \mathrm{l}$ in the southern suburb of Omdurman City and between 128 and $1024 \mathrm{~g}$ in some wells in Grand Khartoum City. Moreover, Abdellah et al. (2012a) reported that, in the Al-Butana region, groundwater salinity tends to decrease by continuous discharge which replaced by fresh recharge from the low salinity Blue Nile water. Conversely, Al-Redhaiman and Abd-Magid (2002) and Munday and Andrew (2008) incriminated over exploitation and excessive water pumping among factors that may elevate salinity level in groundwater. Increasing levels of TDS in some groundwater areas are usually caused by the intrusion of high salinity water due to over-exploitation in aquifers adjacent to seawater or by the replacement of low salinity water with high salinity water in temperate climates (Drisckol, 1986). Sodium concentration $\left(\mathrm{Na}^{+}\right)$ranged from 160 to $922 \mathrm{mg} / \mathrm{l}$ with a mean value of $424 \mathrm{mg} / \mathrm{l}$ thus revealing that about $83 . .3 \%$ of the samples studied are falling above the Standard limit of $200 \mathrm{mg} / \mathrm{l} \mathrm{set}$ by both of the SSMO and WHO standards and guidelines. The WHO guideline for $\mathrm{Na}^{+}(200 \mathrm{mg} / \mathrm{l})$ is based on taste considerations rather than the impact on human health (Raveendran and Madany,1991; AL - Redhaiman and Abdel - Magid ,2002).

\section{Microbiological analysis:}

Table 4 shows the total count values as $\log _{10}$ plate count per $\mathrm{ml}$ for the three study areas. It may be observed that only $25 \%$ of the samples studied showed negative total viable count. On the other hand, $55 \%$ of the samples were contaminated with coliform bacteria (35\% of which are source well water samples and $20 \%$ are Sabeel (public water stands) water samples. The high total viable count of bacteria for the water samples in the study area indicates that the drinking water in the three communities is highly contaminated; the presence of coliform in the studied water samples is an indicator of fecal contamination, especially, in public water stands. This result agrees with a previous study by Abdella et al (2012b), which linked bacterial contamination in public water stands to a variety of factors : among these are the microbially contaminated hands of water consumers, children in particular ; handless cups used for drinking exacerbate bacterial transmission by the contaminated hands that are immersed to various depths into the bulk of the drinking water inside the container ; coverless water containers also facilitates the bacterial accession into drinking water; especially widely open clay-pots. Hamad and Dirar (1982) added that dust storms, unattended domestic animals and insects increase the potential for bacterial contamination as well. Moreover, the absence of the daily cleaning practice, prior to filling the water containers, allows growth of bacteria, algae and other microorganisms, especially in overlooked locations. The hoses that are usually used for filling the containers are another potential source of bacterial contamination (Abdel-Magid ,1997). The mechanism of pathogenic contamination in public water stands is independent of pollution at the groundwater source. Jensen et al. (2004) reported that drinking water of poor rural communities, even if it is obtained from 'safe' sources, it may become contaminated during storage in the house under non hygienic and non-sanitary conditions. Pathogenic effects on human life that are related to water were summarized by Abdellah et al. (2012b) into direct and indirect effects .

\section{Conclusions And Recommendations}

Well drinking water quality in both Samrab and Dardog communities is suitable for human consumption since its physico - chemical characteristics are falling within the permissible limits recommended by the national, regional and international standards and guidelines. However, well drinking water in Hattab 
community is highly saline and is, therefore, not suitable for human consumption. Bacteriological contamination is evident in the drinking water belonging to all of the three communities studied: $55 \%$ of the investigated drinking water samples were found to be contaminated with coliform bacteria since drinking water is distributed by random vendors throughout the study area. Therefore, it is imperative to consider connecting these communities to the municipally treated non - saline drinking water network supply. To avoid microbial contamination, distribution network pipes should be installed throughout the three communities.

\section{Acknowledgement}

The authors are thankful to all of those who contributed to this work and to the Department of Soil and Environment Sciences, Faculty of Agriculture, University of Khartoum, for funding this study.

\section{References}

[1]. Abdellah A.M., (2011). Assessment of the Drinking Water Quality in Some Wells in Al-Butana Region of Sudan, PhD thesis, Department of Soil and Environment Sciences, Faculty of Agriculture, University of Khartoum, Sudan.

[2]. Abdellah A.M., Abdel-Magid H.M and Yahia N.A. (2012a). Assessment of Groundwater Quality in the Al-Butana Region of Sudan. Journal of Applied Sciences, 12(1): 64 -70, 2012.

[3]. Abdellah A.M., Abdel-Magid H.M and Yahia N.A.(2012b). Assessment of Drinking Water Microbial Contamination in the AlButana Region of Sudan. Journal of Applied Sciences, 12(9): 856-862, 2012.

[4]. Abdellah A.M., Abdel-Magid H.M and Yahia N.A. (2013). Previous and Current Status of Groundwater Salinity in East of Blue Nile Communities of Sudan. Greener Journal of Environment Management and Public Safety, 2(1): 40-50.

[5]. Abdellah A.M., Abdel-Magid H.M., El-Tingari M.M.B. and Adam F.A. (2014). Assessment of drinking water quality in Grand Khartoum City, Khartoum State, Sudan. J. Atoms and Molecules, 4(1): 645-655.

[6]. Abdel Magid,H.M. (2016). Pamphlet (Booklet) on Drinking Water: Importance and Characteristics (In Arabic). in preparation.

[7]. Abdel-Magid, H.M., (1997) Assessment of Drinking Water Quality in the Al-Gassim Regiog of Saudi Arabia. Environment International, 23(2): 247-251.

[8]. Abdel Magid H.M., Ibrahim I.S. and Dirar H.A. (1984). Chemical and Microbiological examination of well \& Nile water. Environ. Int. 10: 259-263

[9]. Al-Redhaiman K.N. and Abdel Magid H.M. (2002). The applicability of the local and international water quality guidelines to AlGassim region of central Saudi Arabia. Water,Air and Soil Pollution, 137: 235 - 247.

[10]. APHA (American Public Health Association) (1985). Standard Methods for the Examination of Water and Wastewater. $16^{\text {th }}$ edition. Washington, DC.USA.

[11]. APHA (1998). Standard Methods for the Examination of Water and Wastewater. 18th edition. Washington, DC.USA

[12]. Drisckol, F. (1986). Groundwater and Wells. St. Panl, MN: Tohnson Filtration System, $2^{\text {nd }}$ ed. London, England.

[13]. Hamad, Z.H. and Dirar, H.A. (1982) Microbiological Examination of Sebeel Water, Appl. Environ. Microbiol. 43, $1238-1243$.

[14]. Harigan, W.F. (1998). Laboratory Methods in Food Microbiology, $3^{\text {rd }}$ edn. Academic Press, San Diego, London, Boston, New York, Sydney, Tokyo, Toronto.

[15]. Harigan, W.F. and McCane, M.E. (1976). Laboratory Methods in Food and Dairy Microbiology. Academic Press, London.

[16]. Jensen, P.K., Ensink, J.H.J., Jayasinghe, G., Hoek, W.V., Cairncross, S., Dalsgaard, A. (2004). Domestic Transmission Routes of Pathogens: the Problem of In-house Contamination of Drinking Water During Storage in Developing Countries. Tropical Medicine \& International Health, 7(7): 604-609.

[17]. Munday, T. and Andrew, F. (2008). The Targeted Application of Aim for Salinity Mapping, Interception and Disposal: An Illustration of the Multifarious of Helicopter and Data in Environmental Management across the Murray Basin of Southeast, Australia. $5^{\text {th }}$ International Conference on Airborne Electromagnetics Haikko Manor, Finland: 28-30.

[18]. Perry, A H (1991) 'Climatic Characteristics of Sudan's Capital Region' In: M E Abu-Sin and HRJ Davies (eds) The Future of Sudan's Capital Region: A Study of Development and Change Khartoum University Press, Khartoum.

[19]. Rhoades, J.D. (1982). 'Soluble Salts): In A. L. Page, R. H. Miller and D. R. Keeney (eds), Methods of Soil Analysis, Part 2: Chemical and Microbiological Properties, $2^{\text {nd }}$ ed., American Society of Agronomy, Inc, Madison, Wisconsin, U.S.A: $167-179$.

[20]. Richards,L.A.(1954). Diagnosis and Improvement of Saline and Alkali Soils. Handbook No.60, Washington, D.C. ,U.S. Department of Agriculture.

[21]. Shakesby, RA (1991) 'Relief, Rocks and Sediments in the Capital Region' In: ME Abu-Sin and HRJ Davies (eds) TheFuture of Sudan's Capital Region: A Study of Development and Change Khartoum University Press, Khartoum.

[22]. SASO (Saudi Arabian Standards Organization) (1984), Bottled and Unbottled Drinking Water, SSA 409/1984, $2^{\text {nd }}$ ed. SASO Information Center, P.O. Box 3437, Riyadh, 11471, Saudi Arabia: 1-8.

[23]. Shommo E.I. (2007). Assessment of drinking water quality of wells drilled in the southern suburb of Omdurman City, MSc thesis, Department of Soil and Environment Sciences Faculty of Agriculture, University of Khartoum. Sudan.

[24]. SSMO (Sudanese Standards and Metrology Organization). (2002). Unbottled Drinking Water: Standard NO.044-First edition.

[25]. USEPA (U.S. Environment Protection Agency): (1976), National Interim Primary Drinking Water Regulations, Publication EPA/S 709-76-003. Washington, D.C., U.S.A., Government Printing office.

[26]. WHO. (World Health Organization) (1993). Guidelines for Drinking-water Quality, 1, $2^{\text {nd }}$ ed. Geneva. 


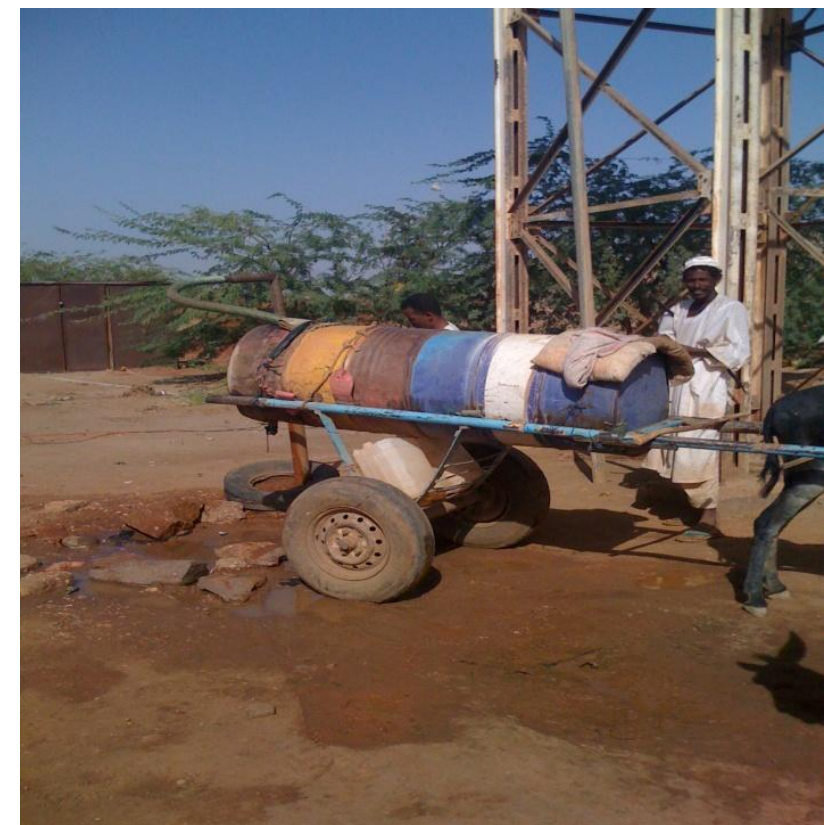

Plate (1): Water vendors are the main source of distributing drinking water in Dardog Community, Khartoum North suburb, Sudan.

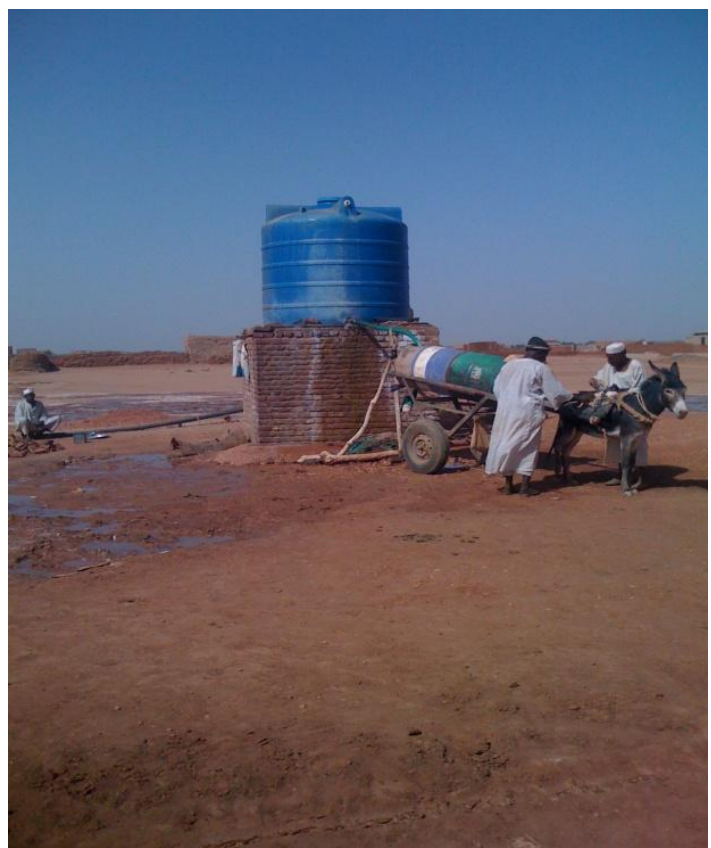

Plate (2): Water reservoirs are widely spread in Hattab Community, Khartoum North suburb, Sudan.

Table (1): Physical and Chemical quality of drinking water samples $(n=8)$ in Samrab community as compared to the national, regional and international standards.*

\begin{tabular}{|c|c|c|c|c|c|c|c|c|c|c|c|}
\hline $\begin{array}{r}\text { Constituent/ } \\
\text { Property }\end{array}$ & Mean & Range & $\begin{array}{r}\text { Standard } \\
\text { deviation }\end{array}$ & $\begin{array}{l}\text { SSMO } \\
(2002)\end{array}$ & $\begin{array}{r}(\%) \text { of } \\
\text { Samples } \\
\text { above }\end{array}$ & $\begin{array}{r}\text { SASO } \\
(1984)\end{array}$ & $\begin{array}{r}(\%) \text { of } \\
\text { samples } \\
\text { above }\end{array}$ & $\begin{array}{r}\text { USEP } \\
\text { A } \\
(1976)\end{array}$ & $\begin{array}{r}(\%) \text { of } \\
\text { samples } \\
\text { above }\end{array}$ & $\begin{array}{r}\text { WHO } \\
(1993)\end{array}$ & $\begin{array}{r}(\%) \text { of } \\
\text { samples } \\
\text { above }\end{array}$ \\
\hline $\mathrm{EC}(\mathrm{ds} / \mathrm{m})$ & 0.45 & $0.28-0.64$ & 0.11 & 1.6 & 0.0 & 2.3 & 0.0 & NS & & NS & \\
\hline $\mathrm{TDS}(\mathrm{mg} / \mathrm{l})$ & 288.8 & $179-409.6$ & 69.1 & 1000 & 0.0 & 1500 & 0.0 & 500 & $0 . \overline{0}$ & 1000 & $0 . \overline{0}$ \\
\hline $\mathrm{Ph}$ & 6.78 & $6.53-7.06$ & 0.17 & $6.5-8.5$ & 0.0 & $6.5-9.2$ & 0.0 & $6.5-8.5$ & 0.0 & $<8$ & 0.0 \\
\hline $\mathrm{Ca}^{+2}(\mathrm{mg} / 1)$ & 2.13 & $1.4-3.5$ & 0.67 & NS & & 200 & 0.0 & 200 & 0.0 & NS & \\
\hline $\mathrm{Mg}^{+2}(\mathrm{mg} / 1)$ & 1.64 & $1.1-2.5$ & 0.43 & NS & & 150 & 0.0 & 150 & 0.0 & NS & \\
\hline $\mathrm{Na}^{+}(\mathrm{mg} / \mathrm{l})$ & 77.3 & $30-141$ & 41.2 & 200 & 0.0 & NS & & NS & & 200 & 0.0 \\
\hline $\mathrm{K}^{+}(\mathrm{mg} / 1)$ & 3.34 & $2.05-4.22$ & 0.7 & NS & & NS & & NS & & NS & \\
\hline $\mathrm{Cl}^{-}(\mathrm{mg} / \mathrm{l})$ & 1.05 & $0.3-1.75$ & 0.56 & 250 & $0 . \overline{0}$ & 600 & $0 . \overline{0}$ & 250 & $0 . \overline{0}$ & 250 & $0 . \overline{0}$ \\
\hline $\mathrm{SO}_{4}^{-2}(\mathrm{mg} / \mathrm{l})$ & 5.7 & $0.0-16.48$ & 4.6 & 250 & 0.0 & 400 & 0.0 & 250 & 0.0 & 400 & 0.0 \\
\hline $\mathrm{NO}_{3}{ }^{-}(\mathrm{mg} / \mathrm{l})$ & 0.53 & $0.3-0.9$ & 0.2 & 50 & 0.0 & $<45$ & 0.0 & 45 & 0.0 & 50 & 0.0 \\
\hline $\mathrm{HCO}_{3}^{-}(\mathrm{mg} / 1)$ & 4.0 & $2.6-4.6$ & 0.66 & NS & & NS & & NS & & NS & \\
\hline
\end{tabular}


* SSMO: Sudanese standards \& Metrology Organization, SASO: Saudi Arabian Standards Organization, USEPA: United States Environmental Protection Agency, WHO: World Health Organization guidelines, NS: No standard

Table (2): Physical and Chemical quality of drinking water samples $(n=6)$ in Dardog community as compared to the national, regional and international standards. *

\begin{tabular}{|c|c|c|c|c|c|c|c|c|c|c|c|}
\hline $\begin{array}{r}\text { Constituent/ } \\
\text { Property }\end{array}$ & Mean & Range & $\begin{array}{c}\text { Standard } \\
\text { deviation }\end{array}$ & $\begin{array}{l}\text { SSMO } \\
(2002)\end{array}$ & $\begin{array}{r}(\%) \text { of } \\
\text { Samples } \\
\text { Above }\end{array}$ & $\begin{array}{l}\text { SASO } \\
(1984)\end{array}$ & $\begin{array}{r}(\%) \text { of } \\
\text { samples } \\
\text { above }\end{array}$ & $\begin{array}{r}\text { USEPA } \\
(1976)\end{array}$ & $\begin{array}{r}(\%) \text { of } \\
\text { samples } \\
\text { Above }\end{array}$ & $\begin{array}{r}\text { WHO } \\
(1993)\end{array}$ & $\begin{array}{r}(\%) \text { of } \\
\text { samples } \\
\text { above }\end{array}$ \\
\hline $\mathrm{EC}(\mathrm{ds} / \mathrm{m})$ & 0.43 & $0.32-0.52$ & 0.08 & 1.6 & 0.0 & 2.3 & 0.0 & NS & & NS & \\
\hline $\mathrm{TDS}(\mathrm{mg} / \mathrm{l})$ & 274.13 & $204-333$ & 51.52 & 1000 & 0.0 & 1500 & 0.0 & 500 & $0 . \overline{0}$ & 1000 & $0 . \overline{0}$ \\
\hline $\mathrm{pH}$ & 6.97 & $6.33-7.45$ & 0.34 & $6.5-8.5$ & 0.0 & $6.5-9.2$ & 0.0 & $6.5-8.5$ & 0.0 & $<8$ & 0.0 \\
\hline $\mathrm{Ca}^{+2}(\mathrm{mg} / \mathrm{l})$ & 1.87 & $1.4-2.2$ & 0.25 & NS & & 200 & 0.0 & 200 & 0.0 & NS & \\
\hline $\mathrm{Mg}^{+2}(\mathrm{mg} / 1)$ & 1.82 & $1.3-2.3$ & 0.3 & NS & & 150 & 0.0 & 150 & 0.0 & NS & \\
\hline $\mathrm{Na}^{+}(\mathrm{mg} / 1)$ & 67.9 & $9.4-111$ & 36.1 & 200 & $0 . \overline{0}$ & NS & & NS & & 200 & $0 . \overline{0}$ \\
\hline $\mathrm{K}^{+}(\mathrm{mg} / \mathrm{l})$ & 3.0 & $2-4.19$ & 0.65 & NS & & NS & & NS & & NS & \\
\hline $\mathrm{Cl}(\mathrm{mg} / \mathrm{l})$ & 0.9 & $0.3-1.5$ & 0.56 & 250 & 0.0 & 600 & 0.0 & 250 & 0.0 & 250 & 0.0 \\
\hline $\mathrm{SO}_{4}^{-2}(\mathrm{mg} / \mathrm{l})$ & 4.8 & $0.0-12.36$ & 4.4 & 250 & 0.0 & 400 & 0.0 & 250 & 0.0 & 400 & 0.0 \\
\hline $\mathrm{NO}_{3}^{-}(\mathrm{mg} / \mathrm{l})$ & 0.55 & $0.4-0.8$ & 0.15 & 50 & 0.0 & $<45$ & 0.0 & 45 & 0.0 & 50 & 0.0 \\
\hline $\mathrm{HCO}_{3}^{-} \cdot(\mathrm{mg} / \mathrm{l})$ & 3.72 & $2.6-4.4$ & 0.65 & NS & & NS & & NS & & NS & \\
\hline $\begin{array}{l}\text { Total coliform } \\
\left(\text { MPN } 100 \mathrm{ml}^{-1} \text { ) }\right.\end{array}$ & - & - & - & Negative & - & Negative & _ & Negative & - & Negative & \\
\hline
\end{tabular}

* SSMO: Sudanese standards \& Metrology Organization, SASO: Saudi Arabian standards Organization, USEPA: United States Environmental Protection Agency, WHO: World Health Organization guidelines, NS: No standard

Table (3): Physical and Chemical quality of drinking water samples $(n=6)$ in Hattab community as compared to the national, regional and international standards.*

\begin{tabular}{|c|c|c|c|c|c|c|c|c|c|c|c|}
\hline $\begin{array}{r}\text { Constituent/ } \\
\text { Property }\end{array}$ & Mean & Range & $\begin{array}{l}\text { Standard } \\
\text { deviation }\end{array}$ & $\begin{array}{l}\text { SSMO } \\
(2002)\end{array}$ & $\begin{array}{r}(\%) \text { of } \\
\text { Samples } \\
\text { Above }\end{array}$ & $\begin{array}{l}\text { SASO } \\
(1984)\end{array}$ & $\begin{array}{c}(\%) \text { of } \\
\text { samples } \\
\text { above }\end{array}$ & $\begin{array}{l}\text { USEPA } \\
(1976)\end{array}$ & $\begin{array}{l}(\%) \text { of } \\
\text { samples } \\
\text { Above }\end{array}$ & $\begin{array}{r}\text { WHO } \\
\text { (1993) }\end{array}$ & $\begin{array}{r}(\%) \text { of } \\
\text { samples } \\
\text { above }\end{array}$ \\
\hline $\mathrm{EC}(\mathrm{ds} / \mathrm{m})$ & 5.15 & $0.88-18$ & 6.0 & 1.6 & 66.7 & 2.3 & 50 & NS & & NS & \\
\hline $\mathrm{TDS}(\mathrm{mg} / \mathrm{l})$ & 3293 & $563-11520$ & 3846 & 1000 & 66.7 & 1500 & 50 & 500 & 100 & 1000 & 66.7 \\
\hline $\mathrm{pH}$ & 7.15 & $6.74-7.52$ & 0.3 & $6.5-8.5$ & 0.0 & $6.5-9.2$ & 0.0 & $6.5-8.5$ & 0.0 & $<8$ & 83.3 \\
\hline $\mathrm{Ca}^{+2}(\mathrm{mg} / \mathrm{l})$ & 2.3 & $1.8-3$ & 0.43 & NS & & 200 & 0.0 & 200 & 0.0 & NS & \\
\hline $\mathrm{Mg}^{+2}(\mathrm{mg} / 1)$ & 5.1 & $1.9-12.5$ & 3.6 & NS & & 150 & 0.0 & 150 & 0.0 & NS & \\
\hline $\mathrm{Na}^{+}(\mathrm{mg} / 1)$ & 424.6 & $160-922$ & 286.16 & 200 & $83 . \overline{3}$ & NS & & NS & & 200 & 0.0 \\
\hline $\mathrm{K}^{+}(\mathrm{mg} / \mathrm{l})$ & 6.62 & $3.45-16$ & 4.63 & NS & & NS & & NS & & NS & \\
\hline $\mathrm{Cl}^{-}(\mathrm{mg} / \mathrm{l})$ & 2.05 & $1.75-2.5$ & 0.27 & 250 & $0 . \overline{0}$ & 600 & $0 . \overline{0}$ & 250 & $0 . \overline{0}$ & 250 & $0 . \overline{0}$ \\
\hline $\mathrm{SO}_{4}^{-2}(\mathrm{mg} / 1)$ & 5.5 & $0.0-16.48$ & 5.32 & 250 & 0.0 & 400 & 0.0 & 250 & 0.0 & 400 & 0.0 \\
\hline $\mathrm{NO}_{3}-(\mathrm{mg} / \mathrm{l})$ & 0.55 & $0.4-0.8$ & 0.15 & 50 & 0.0 & $<45$ & 0.0 & 45 & 0.0 & 50 & 0.0 \\
\hline $\mathrm{HCO}_{3}^{-}(\mathrm{mg} / \mathrm{l})$ & 6.9 & $3.8-12.6$ & 3.39 & NS & & NS & & NS & & NS & \\
\hline
\end{tabular}

* SSMO: Sudanese standards \& Metrology Organization, SASO: Saudi Arabian standards Organization, USEPA: United States Environmental Protection Agency, WHO: World Health Organization guidelines, NS: No standard

Table4: Microbial loads of well water

\begin{tabular}{|c|c|c|c|c|c|c|c|c|}
\hline $\begin{array}{l}\text { Sample } \\
\text { Source }\end{array}$ & $\begin{array}{c}\text { Sample } \\
\text { No. }\end{array}$ & $\begin{array}{l}\text { Index } \\
\text { Per } \\
100 \mathrm{ml}\end{array}$ & $\begin{array}{l}\text { MPN* } \\
95 \% \mathrm{C}\end{array}$ & $\begin{array}{l}\text { oliform } \\
\text { lence** } \\
\text { Limits }\end{array}$ & $\begin{array}{r}\mathrm{MF} \\
\text { Inde } \\
100 \mathrm{ml}\end{array}$ & $95 \%$ & $\begin{array}{l}\text { liform } \\
\text { idence } \\
\text { Limits } \\
\text { Unner }\end{array}$ & $\begin{array}{r}\log _{10} \\
\text { Plate** } \\
\text { Count per ml }\end{array}$ \\
\hline & 1 & $>2400$ & -2 & $P P=1$ & 7 & 1 & 21 & 5 \\
\hline & 2 & $>2400$ & 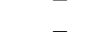 &  & 7 & 1 & 21 & 4 \\
\hline & 3 & 1100 & $150^{-}$ & 4800 & $<3$ & _ & - & 9 \\
\hline & 4 & 93 & 15 & 380 & $<3$ & - & - & _ \\
\hline Samrab & 5 & 23 & 4 & 120 & $<3$ & - & - & $\overline{4}$ \\
\hline & 6 & 9 & 1 & 36 & $<3$ & _ & - & _ \\
\hline & 7 & 4 & $<0.5$ & 20 & $<3$ & - & 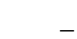 & 3.6 \\
\hline & 8 & 4 & $<0.5$ & 20 & & & & 4.8 \\
\hline & 9 & 210 & 35 & 470 & $<3$ & - & - & 10.6 \\
\hline & 10 & 39 & 7 & 130 & $<3$ & - & - & 50 \\
\hline Dardog & 11 & 39 & 7 & 130 & $<3$ & - & - & 7.5 \\
\hline & 12 & 4 & $<0.5$ & 20 & $<3$ & - & - & 8.8 \\
\hline & 13 & $<3$ & _ & - & $<3$ & - & - & 3 \\
\hline & 14 & $<3$ & 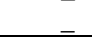 & _ & $<3$ & & _ & $=$ \\
\hline & 15 & $>2400$ & - & - & & $<3$ & & - \\
\hline & 16 & $>2400$ & - & - & 4 & $<0.5$ & 20 & 8 \\
\hline Hattab & 17 & 460 & 71 & 2400 & $<3$ & - & _ & - \\
\hline & 18 & $<3$ & _ & - & $<3$ & - & - & $5 . \overline{7}$ \\
\hline & 19 & $<3$ & - & - & $<3$ & - & - & 3.6 \\
\hline & 20 & $<3$ & - & & $<3$ & - & - & 4.4 \\
\hline
\end{tabular}

* MPN $=$ Most Probable Number, ${ }^{*} *_{-}=$Negative 